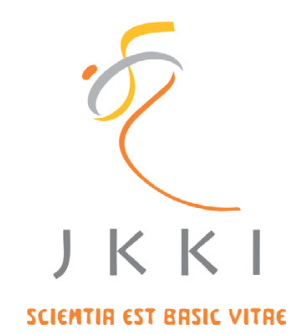

Jurnal Kedokteran dan Kesehatan Indonesia

Indonesian Journal of Medicine and Health

Journal homepage : www.journal.uii.ac.id/index.php/JKKI

\title{
New oral anticoagulants for Atrial Fibrillation
}

Yuliana Yakobus*1

${ }^{1}$ Department of Cardiothoracic Surgery, University Hospital, Halle (Saale), Germany.

Review Article

\begin{tabular}{|c|c|}
\hline & ABSTRACT \\
\hline ARTICLE INFO & Atrial fibrillation (AF) is the most common cardiac arrhythmia in the \\
\hline $\begin{array}{l}\text { Keywords: } \\
\text { Atrial fibrillation } \\
\text { anticoagulants }\end{array}$ & for warfarin in patients with AF. Although the newer aspects have \\
\hline $\begin{array}{l}\text { *Correspondi } \\
\text { yuliana.yakobu }\end{array}$ & anticoagulation monitoring. \\
\hline DOI : 10.20885/JKKI.Vol8.Iss2.art5 & $\begin{array}{l}\text { Fibrilasi atrial (AF) adalah aritmia jantung yang paling umum didunia. } \\
\text { Terdapat empat antikoaqulan oral baru tersedia sebagai alternatif }\end{array}$ \\
\hline $\begin{array}{l}\text { History: } \\
\text { Received: April 15, } 2017 \\
\text { Accepted: May 22, } 2017 \\
\text { Online: June 15, } 2017\end{array}$ & $\begin{array}{l}\text { warfarin pada pasien dengan AF. Meskipun harga obat baru tersebut lebih } \\
\text { mahal, namun terdapat manfaat penghematan biaya yang disebabkan } \\
\text { penurunan kejadian pendarahan dan penurunan kebutuhan untuk } \\
\text { monitoring penggunaan antikoagulan. }\end{array}$ \\
\hline
\end{tabular}

\section{INTRODUCTION}

Atrial fibrillation (AF) is the most common cardiac arrhythmia, currently affecting in $1-2 \%$ of the general population. ${ }^{1}$ The lifetime risk of AF in patients 40 years of age and older is estimated at $25 \%$. $^{2,3}$ Stroke is a major complication associated with AF, which contributes to the morbidity and mortality associated with the disease. Patients with AF have a five-fold increased risk of stroke. In consequence, the risk of death from AF-related stroke is doubled and the cost of care is increased 1.5 fold. 1 This risk varies among patient populations, according to age, sex, and the presence of comorbid disease states (e.g., diabetes, hypertension, congestive heart failure, and vascular disease).,2,5

Anticoagulation is recommended for stroke prevention for intermediate risk and high risk patients (CHADS2 score $\geq 1$, see Table 1). .,6-10 $^{4}$ Previously, warfarin was the only option for oral anticoagulation in these patients. An assessment of bleeding risk should be part of the patient assessment before starting anticoagulation. Despite anticoagulation of more elderly patients with $\mathrm{AF}$, rates of intracerebral haemorrhage are considerably lower than in the past, typically between 0.1 and $0.6 \%$ in contemporary reports. This may reflect lower anticoagulation intensity, more careful dose regulation, or better control of hypertension. Using a 'real-world' cohort of 3978 European subjects with AF from the EuroHeart Survey, a new simple bleeding risk score, HAS-BLED (see Table 2), has been derived. It would seem reasonable to use the HAS-BLED score to assess bleeding risk in AF patients, whereby a score of $\geq 3$ indicates 'high risk', and some caution and regular review of the patient is needed following the initiation of anticoagulation therapy. ${ }^{1}$

Currently, four oral anticoagulants are 
available on the market as alternatives to warfarin in patients with AF. Dabigatran was the first new oral anticoagulant approved for stroke prevention in AF, followed by the oral anti-factor Xa inhibitors rivaroxaban, apixaban and edoxaban. Rivaroxaban is also approved for the treatment of deep vein thrombosis (DVT) and pulmonary embolism (PE), along with prevention of DVT/PE in patients undergoing knee or hip replacement surgeries. ${ }^{11}$ Apixaban was approved for stroke prevention in December 2012.12 Edoxaban was approved for the prevention of stroke and for the treatment of symptomatic venous thromboembolism in $2013{ }^{38,39}$ None of the new agents are approved for use in patients with AF secondary to valvular heart disease or mechanical heart valves. A summary of indications and doses of these oral agents is provided in Table 3. ${ }^{10-12,38,39}$
Table 1. CHADS2 Score

\begin{tabular}{lc}
\hline Congestive Heart Failure & +1 \\
Hypertension & +1 \\
Age $\geq 75$ years & +1 \\
Diabetes Mellitus & +1 \\
Stroke/TIA/Thrombo-embolism & +2 \\
\hline Table 2. HAS-BLED Score & \\
\hline Hypertension & +1 \\
Abnormal liver function & +1 \\
Abnormal renal function & +1 \\
Stroke & +1 \\
Bleeding & +1 \\
Labile INRs & +1 \\
Elderly (Age $>65)$ & +1 \\
Drugs & +1 \\
Alcohol & +1 \\
\hline
\end{tabular}

Table 3.Indications and doses for the new oral anticoagulant

\begin{tabular}{|c|c|c|c|}
\hline & Atrial fibrillation & VTE prevention & VTE treatment \\
\hline Dabigatran & 150 mg b.i.d., 75 mg b.i.d.a & - & - \\
\hline Rivaroxaban & 20 mg daily; 15 mg daily & $10 \mathrm{mg}$ daily ${ }^{\mathrm{d}, \mathrm{e}}$ & $\begin{array}{l}15 \text { mg b.i.d. x } 21 \text { days, } \\
\text { then } 20 \text { mg daily }\end{array}$ \\
\hline Apixaban & $5 \mathrm{mg}$ daily; $2.5 \mathrm{mg}$ daily ${ }^{\mathrm{c}}$ & - & - \\
\hline Edoxaban & 60 mg daily; 30 mg daily ${ }^{f}$ & - & 60 mg daily; 30 mg daily \\
\hline
\end{tabular}

${ }^{\text {a}}$ For patients with a $\mathrm{CrCl}$ of 15 to $30 \mathrm{~mL} / \mathrm{minute}$ or a $\mathrm{CrCl}$ of 30 to $50 \mathrm{~mL} / \mathrm{minute}$ and concomitantly receiving a strong P-glycoprotein inhibitor.

${ }^{b}$ For patients with a $\mathrm{CrCl}$ of 15 to $50 \mathrm{~mL} /$ minute.

'If the patient is taking a strong dual inhibitor of CYP3A4 and a permeability glycoprotein (P-gp) inhibitor, or has two or more of these characteristics: 80 years ofage or older, body weight $\leq 60 \mathrm{~kg}$, or serum creatinine $1.5 \mathrm{mg} / \mathrm{dL}$ or greater.

${ }^{\mathrm{d} P o s t-o p e r a t i v e ~ t h r o m b o p r o p h y l a x i s ~ f o l l o w i n g ~ h i p ~ o r ~ k n e e ~ r e p l a c e m e n t ~ s u r g e r y . ~}$

${ }^{\mathrm{e}}$ Avoid use in patients with a $\mathrm{CrCl}$ of $30 \mathrm{~mL} /$ minute or lower.

b.i.d. = twice daily; $\mathrm{CrCl}=$ creatinine clearance; $\mathrm{CYP}=$ cytochrome $\mathrm{P} 450 ; \mathrm{VTE}=$ venous thromboembolism.

${ }^{\mathrm{f}}$ For patients with a $\mathrm{CrCl}$ of 30 to $50 \mathrm{~mL} /$ minute, bodyweight $\leq 60 \mathrm{~kg}$ or concomitantly receiving a strong P-glycoprotein inhibitor.

\section{Comparison of warfarin and the new oral anticoagulant}

An ideal oral anticoagulant has a rapid onset and predictable pharmacokinetics with easily quantifiable and reversible therapeutic effects. Above all, the medication should be efficacious.
When compared with warfarin, the new oral anticoagulants have a faster onset and predicable pharmacokinetics. ${ }^{11-13}$ In addition, a routine anticoagulation monitoring is not required, and these agents are at least as efficacious as warfarin. 
Warfarin exerts its anticoagulation effect by inhibiting the synthesis of vitamin K-dependent coagulation factors II, VII, IX, and X. The primary pharmacological effect of warfarin results from the inhibition of factor II or thrombin. ${ }^{14}$ More frequent monitoring of the International Normalized Ratio (INR) may be required at the initiation of therapy in order to determine the patient's individual steady-state dose.

Inhibition of multiple vitamin K-dependent coagulation factors and genetic variations of the VKORC1 and cytochrome P450 (CYP) 2C9 enzymes contribute to the variation in dosing required for therapeutic anticoagulation. ${ }^{15-18}$ The amount of dietary vitamin $\mathrm{K}$ consumed can also affect the dosing requirements of warfarin; therefore, dietary intake should remain consistent. Sub-therapeutic anticoagulation therapy may result in thrombosis, yet over-anticoagulation can lead to bleeding complications.

Warfarin also inhibits natural anticoagulant proteins $\mathrm{C}$ and $\mathrm{S}$, resulting in an increased risk of thrombosis at the initiation of therapy. ${ }^{19,20}$ Patients at a high risk of thrombosis (who have a high risk for $\mathrm{AF}$ and acute thrombosis or who have a mechanical heart valve) may need bridge therapy with unfractionated heparin (UFH) or low-molecular-weight heparin (LMWH) until a steady-state concentration is achieved.

A slow onset of action, a narrow therapeutic index, numerous drug and food interactions, variable pharmacokinetics, and the need for monitoring INR are major limitations of the warfarin use in patients with AF. The newer anticoagulants exert their therapeutic effects by directly inhibiting a single factor in the coagulation cascade; dabigatran targets factor IIa, and rivaroxaban, apixaban and edoxaban bind to factor Xa. These new agents also have a more reliable pharmacodynamic profile and provide a less complicated dosing regimen (see Table 4). ${ }^{11-13}$ However, limitations to their use include a higher acquisition cost, its contraindication for patients with severe renal impairment, a lack of an antidote for reversal, and an inability to quantify their effects in routine coagulation testing and limited experience with drug-drug and drug-disease interactions.

Table 4. Pharmacokinetic properties of new oral anticoagulants

\begin{tabular}{lllll}
\hline & Dabigatran & Rivaroxaban & Apixaban & Edoxaban \\
\hline Mechanism of action & $\begin{array}{l}\text { Direct thrombin } \\
\text { inhibitor }\end{array}$ & $\begin{array}{l}\text { Direct factor Xa } \\
\text { inhibitor }\end{array}$ & $\begin{array}{l}\text { Direct factor Xa } \\
\text { inhibitor }\end{array}$ & $\begin{array}{l}\text { Direct factor Xa } \\
\text { inhibitor }\end{array}$ \\
Oral bioavailability & $6 \%$ & $60 \%-80 \%$ & $50 \%$ & $62 \%$ \\
Volume of distribution & $50-70 \mathrm{~L}$ & $50 \mathrm{~L}$ & $21 \mathrm{~L}$ & $107 \mathrm{~L}$ \\
Half-life & $12-17$ hours & $5-13$ hours & $9-14$ hours & $10-14$ hours \\
Metabolism/elimination & $80 \%$ renal & 33\% renal; 66\% & $25 \%$ renal; & $50 \%$ renal; \\
& & hepatic & $75 \%$ fecal & $50 \%$ hepatic \\
Protein binding & $35 \%$ & $>90 \%$ & $87 \%$ & $55 \%$ \\
Approval year by FDA & Oct 2010 & Nov 2011 & DeC 2012 & Jan 2015 \\
\hline
\end{tabular}

\section{Direct thrombin inhibitors Dabigatran}

Dabigatran, a competitive and reversible inhibitor of free and clot-bound thrombin, prevents soluble fibrinogen from converting to fibrin. ${ }^{13,21}$ It is a prodrug that is converted to its active form though esterase catalyzed hydrolysis. ${ }^{13,22}$ Dabigatran is formulated as encapsulated pellets with a tartaric acid core to enhance its oral absorption and to ensure consistent and pharmacologically desirable concentrations. ${ }^{23}$ Crushing or breaking the capsules and administration via a nasogastric (NG) tube should be avoided, because pellet administration outside of the capsule can increase bioavailability by up to $75 \%$. $^{13,23}$ 
In patients with $\mathrm{AF}$, dabigatran $150 \mathrm{mg}$ is taken twice daily with or without food. A reduced dose of $75 \mathrm{mg}$ is recommended if the patient's creatinine clearance $(\mathrm{CrCl})$ is 15 to $30 \mathrm{~mL} /$ minute. Clearance is primarily renal, and the drug is a substrate of permeability glycoprotein (P-gp). The use of dabigatran with P-gp inducers (such as rifampin) should be avoided. The combination of renal impairment and P-gp inhibition has a greater tendency to achieve undesirable concentrations when compared with each factor separately. ${ }^{11-13,24}$

For patients with moderate renal impairment (a $\mathrm{CrCl}$ of $30-50 \mathrm{~mL} /$ minute) who are concomitantly taking P-gp inhibitors such as dronedarone or systemic ketoconazole, a reduced dose of $75 \mathrm{mg}$ is recommended. Approval of the 75-mg dose was based on pharmacokinetic modeling data. ${ }^{13,24}$ The clinical efficacy of the reduced dose regimen has not been studied. ${ }^{6,9-13}$ Significant adverse effects occurring with dabigatran at a rate exceeding $15 \%$ include dyspepsia and gastritis-like symptoms. ${ }^{13}$

Routine monitoring of anticoagulation activity is not necessary if dabigatran is administered according to the manufacturer's recommendations. Dabigatran prolongs thrombin clotting time (TCT), prothrombin time (PT), activated partial thromboplastin time (aPTT), and ecarin clotting time (ECT). TCT, aPTT, and ECT can be used to estimate the drug's serum concentration. However, the degree of aPTT elevation is not linearly correlated with the dabigatran concentration, and it is particularly inaccurate at higher concentrations of the drug. ${ }^{13,15}$

A boxed warning cautions against interruptions in dabigatran therapy to avoid an increased risk of stroke resulting from the drug's short half-life. Therefore, with holding dabigatran for bleeding or invasive surgery should be minimized when possible. ${ }^{13}$ Dabigatran should be with held for 1 to 2 days before an invasive procedure in patients with normal renal function and for 3 to 5 days if the $\mathrm{CrCl}$ is $50 \mathrm{~mL} /$ minute or below. ${ }^{13}$ TCT and aPTT can be used to determine the residual anticoagulation activity of dabigatran before the procedure. ${ }^{15,25}$

There is no known reversal agent for dabigatran. Symptomatic management is the primary approach for bleeding because of dabigatran's relatively short half-life. Recombinant factor VIIa (rFVIIa), prothrombin complex concentrates (PCCs), or hemodialysis can be considered for reversing life-threatening bleeding. ${ }^{25-28}$

\section{Factor Xa Inhibitors Rivaroxaban}

Rivaroxaban (Xarelto) was the first oral reversible factor Xa inhibitor for stroke prevention in nonvalvular AF. It is also approved for treatment of VTE, PE and VTE prophylaxis in patients undergoing knee or hip replacement. ${ }^{9}$ For patients with $\mathrm{AF}$, rivaroxaban $20 \mathrm{mg}$ once daily should be taken with food. Because of the drug's partial renal elimination, the dose should be reduced to $15 \mathrm{mg}$ once daily in patients with a $\mathrm{CrCl}$ of 15 to $50 \mathrm{~mL} /$ minute. $^{11-13}$

Rivaroxaban, also a P-gp substrate, is metabolized by CYP3A4 pathways. The concomitant use with a P-gp and a strong CYP3A4 inhibitor (e.g., a protease inhibitor, ketoconazole, or itraconazole) can lead to increased rivaroxaban exposure by $30 \%$ to $160 \%$, resulting in increased bleeding risk and, therefore, should be avoided. Clinicians should weigh the risks and benefits in patients with renal impairment who are receiving concomitant P-gp and weak-to-moderate CYP3A4 inhibitors such as amiodarone, diltiazem, verapamil, quinidine, erythromycin, and azithromycin. Conversely, rivaroxaban concentrations can be reduced by $50 \%$ with dual P-gp and strong CYP3A4 inducers such as rifampin, phenytoin, carbamazepine; concomitant administration should be avoided..$^{11}$

The use of rivaroxaban in patients with hepatic impairment (a Child-Pugh class of B or C) is not recommended. Additional warnings include an increased risk of thrombotic events with the cessation of rivaroxaban therapy. The drug's half-life is 5 to 9 hours in young, healthy patients (20-45 years of age); its half-life is 11 to 13 hours in elderly people. The peak effect occurs 
2 to 4 hours after administration. Rivaroxaban can also be given by nasogastric tube or a gastric feeding tube. ${ }^{11}$

The most common adverse events with rivaroxaban were related to bleeding and occurred at rates similar to those of warfarin in clinical trials. Non-hemorrhagic adverse drug events reported at a rate of $5 \%$ or more included peripheral edema, dizziness, nasopharyngitis, cardiac failure, bronchitis, dyspnea, and diarrhea, which occurred at rates similar to those receiving warfarin. $^{11}$

Rivaroxaban causes concentration-dependent prolongation of PT and aPTT. Neither the manufacturer nor any organization recommends routine anticoagulation monitoring during rivaroxaban therapy. Factor Xa inhibitors (rivaroxaban, apixaban and edoxaban) have a more pronounced effect on PT than on aPTT. Abnormalities in coagulation tests can be observed with therapeutic doses..$^{31}$ Interruption of therapy should be minimized to reduce the risk of thrombosis. Anticoagulation activity may be prolonged in patients with renal dysfunction because of partial renal clearance. ${ }^{11-13}$ Rivaroxaban should be withheld for at least 1 day before an invasive procedure for patients with normal renal function and longer for patients with renal dysfunction (2 days if the $\mathrm{CrCl}$ is $60-90 \mathrm{~mL} /$ minute, 3 days if the $\mathrm{CrCl}$ is 30 to 59 $\mathrm{mL} /$ minute, and 4 days if the $\mathrm{CrCl} 15$ is $29 \mathrm{~mL} /$ minute)..$^{25,32}$

There is no specific antidote for rivaroxaban. It is not dialyzable, because its protein binding is nearly 95\%. Limited data suggest that four-factor prothrombin complex concentrates (PCCs) and recombinant factor VIIa can be used in cases of life-threatening bleeding. ${ }^{28,33,34}$

\section{Apixaban}

Apixaban is the second oral selective inhibitor of free and clot-bound factor Xa. In patients with $\mathrm{AF}$, apixaban $5 \mathrm{mg}$ twice daily is recommended. A reduced dose of $2.5 \mathrm{mg}$ twice daily is recommended in patients with two or more of the following: age 80 years or older, body weight $60 \mathrm{~kg}$ or less, and a serum $\mathrm{Cr}$ level of $1.5 \mathrm{mg} / \mathrm{dL}$ or higher.

Apixaban is metabolized primarily by the liver CYP enzyme 3A4 and is a substrate of P-gp. A reduced dose of $2.5 \mathrm{mg}$ twice daily is also recommended when apixaban is used concomitantly with a strong dual inhibitor of CYP3A4 and P-gp (i.e., ketoconazole, itraconazole, ritonavir, or clarithromycin). Manufacturers also advise against the concomitant use of apixaban with strong inducers of P-gp and CYP3A4 if the recommended dose for the patient is 2.5 mg (based upon age, body weight, and renal function). Apixaban is not recommended for patients with severe hepatic impairment.

The drug's biological half-life is 12 hours in vivo. ${ }^{12}$ Adverse events with its use were related primarily to bleeding. ${ }^{12,29,30}$

Apixaban produces dose-dependent elevations in aPTT, PT and chromogenic antifactor Xa assay. Abnormalities in coagulation tests (PT and aPTT) can be observed with therapeutic doses. Anticoagulation monitoring with routine tests is not recommended because of the high degree of variation; however, drugspecific chromogenic anti-factor Xa assay can be used to estimate the extent of anticoagulation.35 Renal and hepatic impairment may result in an extended biological half-life.

Apixaban should be withheld 1 to 2 days before an invasive procedure in patients with normal renal function and longer for patients with renal impairment ( 3 days if the $\mathrm{CrCl}$ is 50 to $59 \mathrm{~mL} / \mathrm{minute}$ and for 4 to 5 days if the $\mathrm{CrCl}$ ranges from 30 to $49 \mathrm{~mL} /$ minute). ${ }^{25}$

No antidote is currently available for apixaban; however, PCCs (prothrombin complex concentrates) can be considered for reversal of a life-threatening bleeding episode. In vitro data supporting its use are lacking. . $^{25,28,36}$

\section{Edoxaban}

Edoxaban, a once daily non-vitamin $\mathrm{K}$ antagonist oral anticoagulant, is a direct, selective, reversible

inhibitor of factor Xa (FXa). ${ }^{38-40}$ In healthy subjects, single oral doses of edoxaban result in peak plasma concentrations within 1.0-2.0 hour 
of administration, followed by a biphasic decline. Exposure is approximately dose proportional for once daily doses of 15-150 mg.

Edoxaban is predominantly absorbed from the upper gastrointestinal tract, and oral bioavailability is approximately $62 \%{ }^{64,66}$ Food does not affect total exposure to edoxaban. The terminal elimination half-life in healthy subjects ranges from 10 to $14 \mathrm{~h}$, with minimal accumulation upon repeat once daily dosing up to doses of $120 \mathrm{mg}$. Its clearance mechanisms involve both renal and non-renal pathways to almost equal extents. Intrinsic factors, such as age, sex and race, do not affect edoxaban pharmacokinetics after renal function is taken into account.

Pharmacokinetic modeling and simulation showed that patients with low body weight, moderate-to-severe renal dysfunction, or concomitant use of a potent P-glycoprotein inhibitor should have the edoxaban dose reduced by $50 \% .^{38}$ Oral administration of edoxaban results in rapid changes in anticoagulatory biomarkers, with peak effects on anticoagulation markers (such as anti-FXa), PT and aPTT occurring within 1-2 $\mathrm{h}$ of dosing. ${ }^{40}$ Although no specific antidote for edoxaban is currently available, hemostatic agents reverse its anticoagulant effect. ${ }^{38}$

\section{CONCLUSION}

Four new oral anticoagulants (dabigatran, rivaroxaban, apixaban and edoxaban) provide several advantages over warfarin, including their predictable pharmacokinetic profile, the fact that no routine monitoring is needed, and the incidence of fewer drug-food interactions. Although renal function, bleeding, and compliance may still need to be monitored in patients, the comfort of use may improve persistence with their anticoagulant regimen. ${ }^{37}$

Some limitations to the use of these newer anticoagulants include the lack of a reversal agent, an inability to use them in specific patient populations (such as those with severe renal impairment), a lack of coagulation tests to quantify their effect, and little experience with drug-drug and drug-disease interactions.
Information about the impact of noncompliance, especially given the short half-lives of these agents, is also lacking.

Taking their limitations into consideration, the new agents still offer several advantages when used appropriately in selected patients. Their role is likely to grow as more data become available regarding their long-term use, drugdrug interactions and use in specific patient populations.

\section{REFERENCES}

1. Camm AJ, Kirchhof P, Lip GYH, Schotten U, Savelieva I, Ernst S, et al. Guidelines for the management of atrial fibrillation. European Heart Journal. 2010;31(19):2369-429.

2. Roger VL, Go AS, Lloyd-Jones DM, Adams RJ, Berry JD, Brown TM, et al. Heart disease and stroke statistics--2011 update: A report from the American Heart Association. Circulation. 2011;123(4):18-209.

3. Miyasaka Y, Barnes ME, Gersh BJ, Cha SS, Bailey KR, Abhayaratna WP, et al. Secular trends in incidence of atrial fibrillation in Olmsted County, Minnesota, 1980 to 2000, and implications on the projections for future prevalence. Circulation. 2006;114(2):119-25.

4. Gage BF, Waterman AD, Shannon W, Boechler M, Rich MW, Radford MJ. Validation of clinical classification schemes for predicting stroke: Results from the national registry of atrial fibrillation. The Journal of the American Medical Association. 2001;285(22):2864-70.

5. Lip GYH, Frison L, Halperin JL, Lane DA. Identifying patients at high risk for stroke despite anticoagulation: A comparison of contemporary stroke risk stratification schemes in an anticoagulated atrial fibrillation cohort. Stroke. 2010;41(12):2731-8.

6. You JJ, Singer DE, Howard PA, Lane DA, Eckman MH, Fang MC, et al. Antithrombotic therapy for atrial fibrillation: Antithrombotic therapy and prevention of thrombosis. Chest. 2012;141(2):e531S-e575S.

7. Anderson JL, Halperin JL, Albert NM, Bozkurt B, Brindis RG, Curtis LH, et al. Man- 
agement of patients with atrial fibrillation (compilation of 2006 ACCF/AHA/ESC and 2011 ACCF/AHA/HRS recommendations): A report of the American College of Cardiology/American Heart Association task force on practice guidelines. Circulation. 2013;127(18):1916-26.

8. Wann LS, Curtis AB, Ellenbogen KA, January CT, Lowe JE, Estes NAM, et al. 2011 ACCF/AHA/HRS focused update on the management of patients with atrial fibrillation (update on dabigatran): A report of the American College of Cardiology Foundation/American Heart Association task force on practice guidelines. Circulation. 2011;123(1):1144-50.

9. Camm AJ, Lip GYH, De Caterina R, Savelieva I, Atar D, Hohnloser SH, et al. 2012 focused update of the ESC Guidelines for the management of atrial fibrillation: An update of the 2010 ESC Guidelines for the management of atrial fibrillation-developed with the special contribution of the European Heart Rhythm Association. European Heart Journal. 2012;14(10):1385-413.

10. Furie KL, Goldstein LB, Albers GW, Khatri P, Neyens R, Turakhia MP, et al. Oral antithrombotic agents for the prevention of stroke in nonvalvular atrial fibrillation: A science advisory for healthcare professionals from the American Heart Association/American Stroke Association. Stroke. 2012;43(12):3442-53.

11. Titusville NJ, Jansenn. XARELTO $®$ (rivaroxaban) safely and effectively [Internet]. 2013. Available from: https://www. accessdata.fda.gov/drugsatfda_docs/label/2011/202439s001lbl.pdf

12. Princeton NJ, Bristol-Myers S. Eliquis (apixaban), package insert [Internet]. 2012. Available from: www.fda.gov/medwatch

13. Ridgefield C, Boehringer I. Praxada (dabigatran), package insert [Internet]. 2013. Available from: www.fda.gov/medwatch.

14. Zehnder JL. Drugs used in disorders of coagulation. In: Katzung BG, Masters SB, Trevor AJ, editors. Basic \& Clinical Pharmacology. 12th ed. New York: McGraw-Hill; 2012.
15. Ageno W, Gallus AS, Wittkowsky A, Crowther M, Hylek EM, Palareti G. Oral anticoagulant therapy: Antithrombotic therapy and prevention of thrombosis. Chest. 9th ed. 2012;141:e44S-e88S.

16. Schwarz UI, Ritchie MD, Bradford Y, Li C, Dudek SM, Frye-Anderson A, et al. Genetic determinants of response to warfarin during initial anticoagulation. New England Journal of Medicine. 2008;358(10):9991008.

17. Genetic testing to aid in warfarin (coumadin) dosing. Pharmacist's Letter. 2007;

18. Takahashi $\mathrm{H}$, Echizen $\mathrm{H}$. Pharmacogenetics of warfarin elimination and its clinical implications. Clinical Pharmacokinetics. 2001;40:587-603.

19. Porter RS, Sawyer WT. Warfarin. In: Evans WE, Schentag JJ, SJ, Jusko WJ, editors. Applied pharmacokinetics principles of therapeutic drug monitoring. 3rd ed. Vancouver: Wash: Applied Therapeutics; 1992.

20. Warrel DA, Cox TM, Firth JD. Oxford textbook of medicine. 4th ed. Oxford, United Kingdom: Oxford University Press; 2003.

21. De Caterina R, Husted S, Wallentin L, Agnelli G, Bachmann F, Baigent C, et al. Anticoagulants in heart disease: Current status and perspectives. European Heart Journal. 2007;28(7):880-913.

22. Stangier J, Clemens A. Pharmacology, pharmacokinetics, and pharmacodynamics of dabigatran etexilate, an oral direct thrombin inhibitor. Clinical and Applied Thrombosis/Hemostasis. 2009;15(Suppl. 1):9S-16S.

23. Norgard NB, Dinicolantonio JJ, Topping TJ, Wee B. Novel anticoagulants in atrial fibrillation stroke prevention. Therapeutic advances in chronic disease. 2012;3(3):12336.

24. Liesenfeld KH, Lehr T, Dansirikul C, Reilly PA, Connolly SJ, Ezekowitz MD, et al. Population pharmacokinetic analysis of the oral thrombin inhibitor dabigatran etexilate in patients with non-valvular atrial fibrillation from the RE-LY trial. Journal of Thrombosis and Haemostasis. 2011;9(11):216875. 
25. Baron TH, Kamath PS, McBane RD. Management of antithrombotic therapy in patients undergoing invasive procedures. New England Journal of Medicine. 2013;368(22):2113-24.

26. Van Ryn J, Stangier J, Haertter S, Liesenfeld $\mathrm{K}$, Wienen W, Feuring M, et al. Dabigatran etexilate - A novel, reversible, oral direct thrombin inhibitor: Interpretation of coagulation assays and reversal of anticoagulant activity. Thrombosis and Haemostasis. 2010;103(06):1116-27.

27. Chang DN, Dager WE, Chin AI. Removal of dabigatran by hemodialysis. American Journal of Kidney Diseases. 2013;61(3):487-9.

28. Kalus JS. Pharmacologic interventions for reversing the effects of oral anticoagulants. American Journal of Health-System Pharmacy. 2013;70:S12-21.

29. Connolly SJ, Eikelboom J, Joyner C, Diener H, Hart R, Golitsyn S, et al. Apixaban in patients with atrial fibrillation. New England Journal of Medicine. 2011;364(9):806-17.

30. Granger CB, Alexander JH, McMurray JJV, Lopes RD, Hylek EM, Hanna M, et al. Apixaban versus warfarin in patients with atrial fibrillation. New England Journal of Medicine. 2011;365(11):981-92.

31. Carter NJ, Plosker GL. Rivaroxaban: A review of its use in the prevention of stroke and systemic embolism in patients with atrial fibrillation. Drugs. 2013;73(7):71539.

32. Hart RG, Eikelboom JW, Ingram AJ, Herzog CA. Anticoagulants in atrial fibrillation patients with chronic kidney disease. Nature Reviews Nephrology. 2012;8(10):569-78.

33. Eerenberg ES, Kamphuisen PW, Sijpkens MK, Meijers JC, Buller HR, Levi M. Reversal of rivaroxaban and dabigatran by prothrombin complex concentrate: A randomized, placebo-controlled, crossover study in healthy subjects. Circulation. 2011;124(14):1573-9.

34. Marlu R, Hodaj E, Paris A, Albaladejo P, Crackowski J, Pernod G, et al. Effect of non-specific reversal agents on anticoagulant activity of dabigatran and rivaroxaban. Thrombosis and Haemostasis.
2012;108(08):217-24.

35. Barrett YC, Wang Z, Frost C, Shenker A. Clinical laboratory measurement of direct factor Xa Inhibitors: Anti-Xa assay is preferable to prothrombin time assay. Thrombosis and Haemostasis. 2010;104(12):1263-71.

36. Martin A, Le Bonniec B, Fischer A, Marchand-Leroux C, Gaussem P, Samama C, et al. Evaluation of recombinant activated factor VII, prothrombin complex concentrate, and fibrinogen concentrate to reverse apixaban in a rabbit model of bleeding and thrombosis. International Journal of Cardiology. 2013;168(4):4228-33.

37. Zalesak M, Siu K, Francis K, Yu C, Alvrtsyan $\mathrm{H}$, Rao $\mathrm{Y}$, et al. Higher persistence in newly diagnosed nonvalvular atrial fibrillation patients treated with dabigatran versus warfarin. Circulation: Cardiovascular Quality and Outcomes. 2013;6(5):567-74.

38. Giugliano RP, Ruff CT, Braunwald E, Murphy SA, Wiviott SD, Halperin JL, et al. Edoxaban Versus warfarin in Patients with atrial fibrillation. New England Journal of Medicine. 2013;369(22):2093-104.

39. Büller HR, Décousus H, Grosso MA, Mercuri M, Middeldorp S, Prins MH, et al. Edoxaban versus warfarin for the treatment of symptomatic venous thromboembolism. New England Journal of Medicine. 2013;369(15):1406-15.

40. Parasrampuria DA, Truitt KE. Pharmacokinetics and pharmacodynamics of edoxaban, a non-vitamin $\mathrm{k}$ antagonist oral anticoagulant that Inhibits clotting factor Xa. Clinical Pharmacokinetics. 2016;55(6):641-55. 